Cristian, Réka M.. "The Life and Times of Karola Szilvássy, A Transylvanian Aristocrat and Modern Woman.” Hungarian Cultural Studies. e-Journal of the American Hungarian Educators Association, Volume 12 (2019) DOI: 10.5195/ahea.2019.359

\title{
The Life and Times of Karola Szilvássy, Transylvanian Aristocrat and Modern Woman
}

\section{Réka M. Cristian}

\begin{abstract}
In this study Cristian surveys the life and work of Baroness Elemérné Bornemissza, née Karola Szilvássy (1876 - 1948), an internationalist Transylvanian aristocrat, primarily known as the famous literary patron of Erdélyi Helikon and lifelong muse of Count Miklós Bánffy de Losoncz, who immortalized her through the character of Adrienne Milóth in his Erdélyi trilógia ['The Transylvanian Trilogy']. Research on Karola Szilvássy is still scarce with little known about the life of this maverick woman, who did not comply with the norms of her society. She was an actress and film director during the silent film era, courageous nurse in the World War I, as well as unusual fashion trendsetter, gourmet cookbook writer, Africa traveler - in short, a source of inspiration for many women of her time, and after.
\end{abstract}

Keywords: Karola Szilvássy, Miklós Bánffy, János Kemény, Zoltán Óváry, Transylvanian aristocracy, modern woman, suffrage, polyglot, cosmopolitan, Erdélyi Helikon

Biography: Réka M. Cristian is Associate Professor, Chair of the American Studies Department, University of Szeged, and Co-chair of the university's Inter-American Research Center. She is author of Cultural Vistas and Sites of Identity: Literature, Film and American Studies (2011), co-author (with Zoltán Dragon) of Encounters of the Filmic Kind: Guidebook to Film Theories (2008), and general editor of AMERICANA E-Journal of American Studies in Hungary, as well as its e-book division, AMERICANA eBooks. cristian@ lit.u-szeged.hu

Baroness Elemérné Bornemissza, née Karola Szilvássy de Cseszelice (1876 - 1948), was born in the Habsburg Empire, in Transylvania's capital Kolozsvár (Cluj-Napoca / Klausenburg) to one of the wealthiest Hungarian families as the daughter of Countess Antónia Wass de Czege and landowner Béla Szilvássy de Cseszelice. When she was twenty, she married the affluent Baron Elemér Bornemissza (1868-1938) with whom she had a child, Hubert, who was born in 1896 and died in 1903 of scarlet fever. Although the Bornemisszas never divorced, they lived separately after their child's death. During the historical period when women first began to enter

\footnotetext{
* I would like to express my gratitude to Enikő Bollobás, professor of literature, Eötvös Loránd University, Budapest. Her insightful and supportive comments helped my text in countless ways. I am also grateful to the editor-in-chief of Hungarian Cultural Studies, Louise O. Vasvári, Stony Brook University and New York University, whose perceptive eye for detail contributed much to the shape of the final product.
} 
Cristian, Réka M.. "The Life and Times of Karola Szilvássy, A Transylvanian Aristocrat and Modern Woman.” Hungarian Cultural Studies. e-Journal of the American Hungarian Educators Association, Volume 12 (2019) DOI: 10.5195/ahea.2019.359

universities and be trained as doctors, professional photographers and filmmakers, Szilvássy figured among these pioneers. As Jaap Scholten remarked in Comrade Baron: A Journey Through the Vanishing World of Transylvanian Aristocracy, Karola Szilvássy was an intelligent, strong woman with a powerful personality that permeated the entire house, famous for being the center point of Transylvanian literary life and a true maverick (Scholten 2016: 100-101). She acted as the muse of prominent politicians and inspired various artists, while she was herself attracted to various art forms, other than organizing numerous artistic and literary events and acting in several plays. Not only a member of the most important literary and art circles of the period in Transylvania, Szilvássy was also a pioneer in the Hungarian film world and even directed a short film sketch during the silent film era.

The first decades of the twentieth century in Transylvania's "dramatic world of Biblical dimensions" (Bollobás 2011) were turbulent historical times even for a highly educated, upperclass, progressive woman. During these years, Szilvássy was the president of the Kolozsvári Nöszövetség ['Women's Association of Kolozsvár'] and permanent member of the Óváry-szalon ['Ovary literary salon'] that numbered among its guests numerous writers and artists including Aladár Kuncz, Sándor Hunyady, Ottó Indig, László Grois, Miklós Bánffy, János Kemény and his wife, Auguszta Paton, Emil Grandpierre, Miklós Krenner, Károly Kós, Jenő Dsida, Zsigmond Móricz, Zsolt Harsányi, Frigyes Karinthy and Dezső Kosztolányi (Sas 1997: 33). She was also a member of the Marosvásárhelyi Kemény Zsigmond Irodalmi Társaság ['Zsigmond Kemény Literary Society of Marosvásárhely/Târgu-Mureş/Neumarkt'], vice-president of the Erdélyi Színpártoló Társaság ['Transylvanian Theater Patrons' Society'], patroness of the literary journal, Erdélyi Helikon ['Transylvanian Helikon'], and one of the main supporters and sponsors of the Református diakonisszamozgalom ['Reformate Deaconess Movement']. An altruist polymath, she was also an ardent fundraiser for the causes of orphanages, young women and old peoples' homes, while also helping to build schools and aiding various Transylvanian art projects.

According to Samu Csinta (2016: 65), Szilvássy was a true cosmopolitan character and an extravagant woman. Moreover, as all witnesses agree, Karola was one of the most fashionable women in Austro-Hungarian Monarchy and always dressed in the latest fashion that was carried out with a leading-edge style of her own (Sas 1997: 32, Ovary 1999: 32, Kemény 1972: 281). In addition, this internationalist baroness possessed exceptional knowledge of literature and the arts. A true polyglot, she spoke Hungarian, German, French, English, and Italian (Sas 1997: 32). Szilvássy understood that culture - and especially that of the multiethnic, mosaic-like world of Austria-Hungary - involves the permanent task of being able to translate beyond the realm of the geographical state and ethnic entity. Similar to many of her contemporaries, all children of a polyglot empire, such as Karl Kraus, Robert Musil, Joseph Roth, Elias Canetti, Paul Celan, Ludwig Wittgenstein, and many others living then in the Habsburg Monarchy, with her tongue set free and knowledge of many languages Szilvássy became, with Marjorie Perloff's (Perloff 2016: 11, 122-123) words, "the emblem less of one particular individual than of a cultural condition." She would use these languages with ease and sophistication when spending the two hottest months of every year in her favorite city, Venice, where she had entrance to the drawing rooms of all the leading Venetian families (Ovary 1999: 32).

Szilvássy's non-conformism and extraordinary personality made her one of the emblematic figures of early twentieth-century Transylvania. An eccentric figure, she was feared by many fellow aristocrats, who viewed her as dangerous because she neglected the rigid 
Cristian, Réka M.. "The Life and Times of Karola Szilvássy, A Transylvanian Aristocrat and Modern Woman." Hungarian Cultural Studies. e-Journal of the American Hungarian Educators Association, Volume 12 (2019) DOI: 10.5195/ahea.2019.359

conventions of Transylvanian nobility. Szilvássy lived freely and was a constant advocate of women's autonomy. She was proud and forthright, a brave woman making other women jealous because she was no hypocrite and never made a secret of her lovers (Scholten 2016: 98). As a young woman, Szilvássy often provoked scandal with her conduct aimed at rebelling against backward Viennese conventions. For example, she had a strong aversion against the obligatory presence of the garde-de-dame ['ladies' companions'] while conversing with men and naturally only loved books that were clearly not "appropriate" for young ladies. With her commanding presence, Szilvássy could not stand rigid societal laws and ossified aristocratic etiquettes for girls and women and behaved as a genuine English suffragette filled with enthusiasm and support for the cause of women's votes worldwide: she strongly believed in the equality of women with men and, as a self-proclaimed internationalist, surrounded herself only with interesting and intriguing people who were as rebellious and courageous as she (Kemény 1972: 281-282). (In Hungary, partial voting rights were granted at the beginning of 1919 for women over thirty who met certain educational and economic criteria; universal suffrage was only achieved in 1945).

As one of the researchers of the Szilvássy's life and work and historian, Zsuzsa Szebeni, (2018) pointed out, it is difficult to characterize this exceptional woman. Interestingly, Szebeni consistently writes Szilvássy's given name with the more universal spelling of 'Carola,'a spelling that emphasizes both her cosmopolitan character and the fact that she could not fit into any local stereotypes of her age. As the researcher wrote, Szilvássy was rather deviant for an aristocrat and amateur for an actress. Similar to contemporary wealthy Jewish salonnières of the fin de siècle Hungary, such as the literary circle headed by Cecil Wohl Pollacsek whose bourgeois cosmopolitan salons hosted a plethora of various intellectuals and artists (Vasvári 2013: 212), Szilvássy was too experienced to be a dilettante in the arts. Moreover, as Szebeni claims, she was also overqualified to be a midwife and nurse, yet had no official physician's diploma. (The first Hungarian woman to gain a medical doctor's diploma in 1879 in Zürich was Vilma Hugonnai, but she was forbidden to practice until 1879; interestingly, Sarolta Steinberger was the first woman who qualified in Hungary as a physician in 1900.) While Szilvássy's own belles lettres writings were scarce, she was the mentor, catalyst and editor of the most important literary works of her age in Transylvania. Her personality displayed clear dramatic traits, rendering her a truly histrionic figure whose life is worth a more in-depth investigation.

In spite of the work done by Szebeni, research on Szilvássy remains insufficient as little is known about her private life, her relations with the other special women of her time and especially about her written works. Most of the information available today regarding Szilvássy consists of brief biographical data with only few historical documents available for detailed study. Nevertheless, the past decade has represented a step forward in a more extensive investigation of her life. The first breakthrough came with the publication of her cookbook, Kipróbált receptek ['Tried Recipes'] in 1998, followed by various studies. Beginning in 2010 a number of exhibitions held in Budapest, Kolozsvár (Cluj-Napoca/Klausenburg), Sepsiszentgyörgy (Sf. Gheorghe/Sankt Georgen), Brassó (Braşov/Kronstadt), Bucharest, Nagyvárad (Oradea/Großwardein), Marosvécs (Brâncoveneşti/Wetsch) as well as several public talks that rejuvenated the iconic figure of this subversive aristocrat within the public realm by piecing together bits of information gathered from various personal and public documents, firsthand accounts of her contemporaries' memoirs and other, mostly literary sources. The most documented years of Szilvássy's life are those spanning the first and the second decade of the twentieth century, while most of the information originating from the thirties and forties-when 
Cristian, Réka M.. "The Life and Times of Karola Szilvássy, A Transylvanian Aristocrat and Modern Woman." Hungarian Cultural Studies. e-Journal of the American Hungarian Educators Association, Volume 12 (2019) DOI: 10.5195/ahea.2019.359

she gradually withdrew from the public life-is still being processed. Following her death in 1948, her legacy in communist Romania was kept secret while her memory was surrounded in silence. Her figure was almost wiped out of the period's history along with the history of most of Transylvanian nobility. As Jaap Scholten wrote, the aristocracy,

was officially outlawed in Hungary and Romania in 1947. The use of coats of arms, titles and double-barreled surnames was forbidden. All good communists were henceforth to address one another as 'comrade,' but tradition proved resilient. Báró elvtárs ['Comrade Baron'] became the oft-used form of address Hungarians and Transylvanians settled upon for the downgraded aristocracy combined the mandatory egalitarianism of communism with the prohibited desire for a class-based society" (2016: 24).

Szilvássy, however, managed never to become a "comrade baroness." A legend in her own time, she was secretive about her private life and decided to keep safe the nine boxes of her personal papers, five of which contained her correspondence conducted with three hundred and thirty-three writers, politicians, artists, friends, and relatives. Another box contained institutional correspondence, travels and war memoirs, while two boxes held personal and family documents. Another one was reserved for administrative issues and manuscripts; one contained newspaper clippings, programs, invitation, drawings, sketches and photographs. For decades these boxes were left in the care of the Erdélyi Református Egyházkerület ['Archives of the Transylvanian Reformate Diocese'] (Csapody 2016: 64) and were opened in 1995, when Kinga Dombi organized the intellectual estate, an effort that was completed in 1999. An unpublished manuscript entitled Bornemisszáné Szilvássy Carola levelezése ("Bornemissza Elemérné Szilvássy Carola hagyatéka”) ['The Correspondence of Mrs. Bornemissza Szilvássy Carola. Estate of Elemérné Bornemissza Carola Szilvássy’] 2014) records further details regarding Szilvássy's legacy.

While the documents contained in Szilvássy's archives are still under examination today, at the beginning of the 1990s, literary historian Ildikó Marosi was given a book with a mossgreen cover that contained Karola's handwritten recipes, a volume that had been presented to Augusta Paton Kemény, the Scottish-Greek wife of Baron János Kémeny of Marosvécs (Brâncovenești / Wetsch). Interestingly, it is this collection of recipes that became the first document to revive Szilvássy's faded image for large numbers of readers. Entitled Kipróbált receptek ['Tried Recipes'], the book was first published in 1998 by Pallas-Akadémia in Csíkszereda (Miercurea Ciuc/Szeklerburg) and became an instant hit. A series of reprints followed in 2001, 2007 and 2009; another, updated version appeared in 2015. This final edition was published by Helikon in Kolozsvár and entitled Receptek: Az erdélyi föuri konyha titkai ['Recipes: The Secret Recipes of the Transylvanian Nobility Kitchen'] once more garnered success. As Zsolna Ugron, a writer in her own right, stated in the opening remarks of the 2015 book launch, the volume's popularity was primarily due to its author, because Szilvássy was "Transylvania's last noble lady, a woman whose name can only be written with an exclamation mark" (Szántai 2015). The recipes found in Karola's initial, moss-green notebook were only slightly edited, with the orthography left intact because publishers wanted to maintain the cultural value and use of the connoisseur's language. Kipróbált receptek includes an array of recipes from around the world, showing that Szilvássy was not only a skilled master of the 
culinary culture of her age (she enjoyed cooking for the guests of her salon and various other gatherings) but also a very open-minded, cosmopolitan person and generous host of diverse communities. Her cookbook has significant value for the cultural history of Central Europe in general and of Transylvania in particular for portraying a way of life that vanished after the World War II. The contents of Kipróbált receptek unveil a pragmatic cosmopolitanism along with the detectable Transylvanianist attitude (Marosi 2009: 5) that was also endorsed by the work of Szilvássy's friends, the architect, writer, illustrator, and ethnologist Károly Kós and Count János Kemény. Among many other dishes, the verbatim descriptions of halpuding ['fish pudding'], sóska-puree ['sorrel puree'], musakka ['moussaka'], brinzovnik ['cheese pastry'], pozsonyi perec ['Bratislava pretzel'], oláh palacsinta ['Vlach pancake'], aubergine-saláta ['eggplant salad'], birsalmasajt ['jellied quince'], eper-parfait ['strawberry parfait'], Richelieu pulyka ['Richelieu turkey'], amerikai bomba ['American bomb'], Provance-torta ['Provence cake'], hideg gesztenye pudding ['cold sweet chestnut pudding'], imambaldi, török ['imambaldi Turkish eggplants'], céklaleves ['beetroot soup'], görög tök, papucs ['Greek squash'], olasz citrom-és tojás-sauce-os apróhús ['Italian minced meat in lemon and egg sauce'], shepherd's pie, uborkaleves ['cucumber soup'], keleti lencseleves ['Oriental lentil soup'], and nyúlpástétom ['rabbit pâté'] (Marosi 2009: 38-181) reflect the life of wealthy aristocrats and their dietary practices, unveiling a way of life that communist regimes in Central Europe managed to erase.

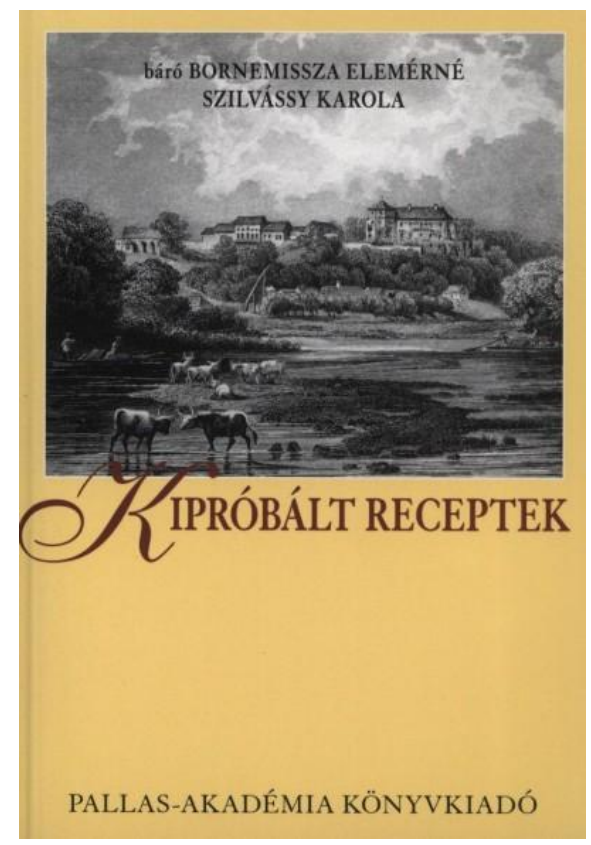

The 1998 edition of Kipróbált receptek ['Tried Recipes'] 


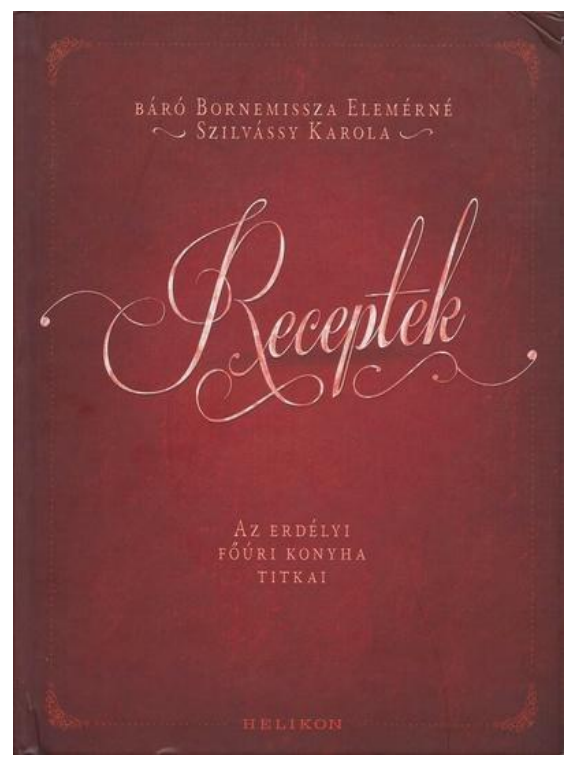

The 2015 edition of Kipróbált receptek ['Tried Recipes']

Apart from the information given by her cookbook, the intriguing image of Szilvássy can be accurately reconstructed based on various other contemporaneous factual accounts, memoirs and literary works. Zoltán Óváry's book Souvenirs. Around the World in Ninety Years. A Book of Memoirs is one such writing. The author-whose English name is spelled Zoltan Ovary- (b. 1907, Kolozsvár - d. 2005, New York) was, according to the founding scientific and medical director of US Cancer Research Institute Lloyd J. Old, "one of the legendary pioneers in immunological research" (in Ovary 1999: ix-x). His parents hosted the famous literary Óváryszalon in Kolozsvár. As Ovary recalls in his memoirs,

[a] remarkable member of the 'guest family' was my godmother, the Baroness Karola Bornemissza. (The name Bornemissza has become well-known internationally because of the art collector, Baron Johan-Heinrich Thyssen-Bornemisza ...but somewhere along the way this branch had dropped an "s" from the name and found its way to the Netherlands and Switzerland.) The Bornemisszas were of high Transylvanian aristocracy, descendants of princes who ruled Transylvania after the Battle of Mohács in 1526, when Transylvania separated from Hungary and became independent principality (Ovary 1999: 32).

Another member of the so-called guest family of the Ovary-salon was Count Miklós Bánffy de Losoncz (who wrote under the penname of Miklós Kisbán, 1873-1950), a scion of Transylvania's most prominent Hungarian aristocratic families, a liberal politician, Renaissance man and noted writer (David 23012; Ovary 1999: 35). Bánffy and Szilvássy were close friends and Szilvássy became the heroine of Bánffy's novel, Erdélyi trilógia ['The Transylvanian Trilogy']. Literary historian Gyula Dávid (2012) stylishly epitomized this Transylvanian as the inconvenient grand seigneur, who declined to pursue the customary political career of his family and class by becoming a decisive figure in the interwar period of Transylvanian literature. Bánffy was the director of the Magyar Állami Operaház ['Hungarian Opera House'] and Nemzeti 
Cristian, Réka M.. "The Life and Times of Karola Szilvássy, A Transylvanian Aristocrat and Modern Woman.” Hungarian Cultural Studies. e-Journal of the American Hungarian Educators Association, Volume 12 (2019) DOI: 10.5195/ahea.2019.359

Színház ['Hungarian National Theater'] between 1913 and 1918, where he oversaw, among many other famous productions, the first performance of composer Béla Bartók's works. He then became the Foreign Minister of Hungary between 1921 and 1922. According to Patrick Thursfield (qtd. in Bánffy 1999: xii), Bánffy was Hungarian by birth but a "very special sort of Hungarian in that his family sprung from Transylvania; and Transylvania, Hungary's greatest lost province, conjures up to Hungarians a totally different picture from that of the Dracula country of Bram Stoker's novel and innumerable horror films made in Europe and America." He was, as Thursfield claims, not only a prolific and talented writer and artist but also one of the leading spirits in founding a publishing house to encourage Transylvanian writers in Hungarian to become better known and retain their identity in the face of Romanian domination. This publishing house was the Erdélyi Helikon ['Translyvanian Helikon'], which became a 'nest' for many artists of various nationalities that were part of the Helikon movement of Marosvécs (1926-1944). As Ovary (1999: 37) writes, the name of Helikon came from the castle owned by one of the members, János Kemény. In this castle, the Helikon group held yearly conferences and a number of its members eventually published books that become part of Hungary's literary pantheon (most notably Károly Kós, Áron Tamási, Irén Gulácsy, Sándor Hunyadi and Aladár Kuncz among many others). The Helikon movement was a free writers' association with a powerful democratic spirit termed as the literary Noah's ark that saved Transylvanian Hungarian literature during the maelstrom of the turbulent historical events that occurred during the 1920s and 1930s. An eloquent example in this sense was the stipend of 100,000 lei that Helikon gave to Antal Szerb, one of the major Hungarian writers of the twentieth century, for his work entitled $A$ magyar irodalom története ['History of Hungarian Literature']. In 1934, Szerb handed the manuscript over to Helikon's most powerful mentor, Karola Szilvássy, who was instrumental in the publication of this work (Csinta 2016: 23, 24, 28; Szebeni qtd. Csapody 2016: 59). (During World War II, Szerb's work was put on the list of forbidden works in 1943, he himself was beaten to death in 1945 and the complete, uncensored work did not become available again until 1990.)

Szilvássy was among the very few revolutionary women of Hungary, whose unconventional life, civil empathy, and love of the arts made her not only an influential personality of her times but also the main character in Bánffy's The Transylvanian Trilogy (1934-1940). Szilvássy and Bánffy first met when they were seventeen and twenty, respectively. Although they fell in love, Bánffy's strict father opposed having his son marry the intrepid Karola. Three years after they met, she married Elemér Bornemissza, but the count remained unmarried until 1939 when, after his father's death, Bánffy finally wed the actress Aranka Gizella Mária Váradi (1886-1966), a celebrated member of the Nemzeti Színház ['Hungarian National Theater']. According to Katalin Bánffy's memoir Ének az életböl ['Song from Life'] (2014), when Bánffy met Váradi she was already married to the prominent gynecologist and medical historian, Sándor Fekete (1885-1972), but her union was (similar to Karola's) infelicitous. With the consent of Fekete, Bánffy and Váradi started a relationship and had a daughter, Katalin (b. 1924), who was adopted fifteen years later by her biological father, Bánffy. During his life, it seems that the count was attracted to two of Transylvania's modern and acccomplished women: Szilvássy and Váradi, but—as all sources state—Szilvássy remained his true love. 
Cristian, Réka M.. "The Life and Times of Karola Szilvássy, A Transylvanian Aristocrat and Modern Woman.” Hungarian Cultural Studies. e-Journal of the American Hungarian Educators Association, Volume 12 (2019) DOI: 10.5195/ahea.2019.359

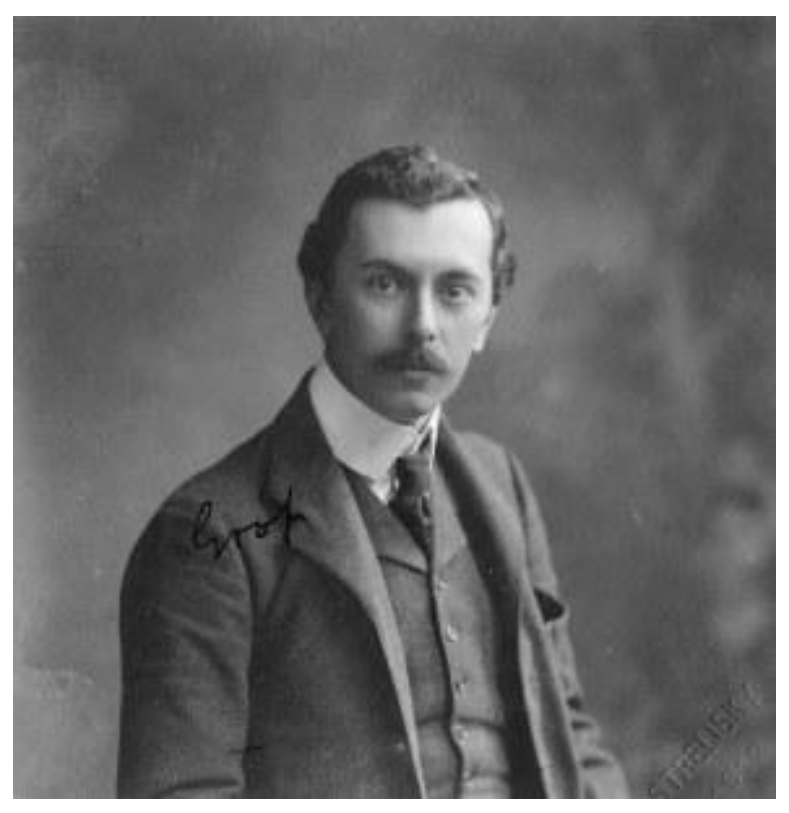

Count Miklós Bánffy de Losoncz

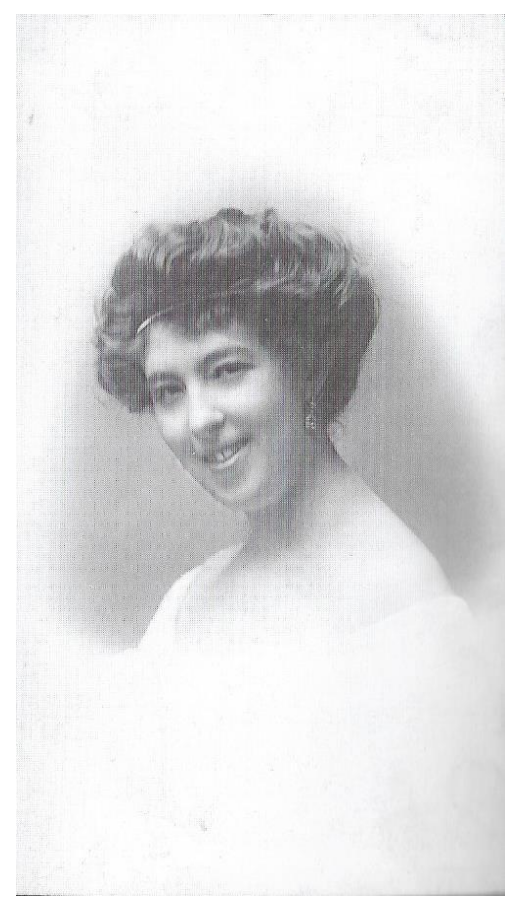

Aranka Váradi

The love between Szilvássy and Bánffy stood the test of time and lasted for over fifty years as an amitié amoureuse (Csapody 2016: 54), becoming one of the best known creative historical romances of the twentieth-century Transylvanian and Hungarian aristocracy. Bánffy immortalized their story in The Transylvanian Trilogy, originally titled Írás a falon ['The 
Cristian, Réka M.. "The Life and Times of Karola Szilvássy, A Transylvanian Aristocrat and Modern Woman.” Hungarian Cultural Studies. e-Journal of the American Hungarian Educators Association, Volume 12 (2019) DOI: 10.5195/ahea.2019.359

Writing on the Wall'], a roman à clef chronicling the declining Transylvanian aristocracy and consisting of three volumes: Megszámláltattál ['They Were Counted,' 1934], És hijjával találtattál ['And Found Wanting,' 1935], Darabokra szaggattatol ['They Were Divided,' 1940]. The trilogy, translated into English in 1999 by Bánffy's daughter, Katalin Bánffy-Jelen and Patrick Thursfield, is currently enjoying a growing acclaim in the international arena. As Thursfield (in Bánffy 1999: xi) notes in the "Introduction" of the first volume, the trilogy is,

ostensibly a love story...but the real theme of this extraordinary family saga is the folly and insularity of the Hungarian upper classes, who danced and quarreled their way to self-destruction in the ten years leading up to the Great War; and the insularity of the politicians who were so pre-occupied with their struggle against Hapsburg domination that they saw nothing of the storm-clouds gathering over Europe.

In the "Foreword" of the first volume, Patrick Leigh Fermor (qtd. in Bánffy 1999: vii) writes that the prejudices and the follies of the trilogy's characters are portrayed from the proper perspective and only semi-censoriously while underscoring that Bánffy's "patriotic feelings are totally free of chauvinism, just as his instinctive promptings of tribal responsibility have not a trace of vanity" in this story.

Szilvássy was the model for the character of Uzdyne Adrienne Miloth (Úzdyné Adrienne Milóth) ['Mrs. Adrienne Miloth Uzdy'], with whom Count Balint Abady (Bálint Abády) is deeply in love - and she was also the first to read the novel after Bánffy finished it. Adrienne's name is a pseudonym, as well as a cryptonym that hides its real referent (Karola Szilvássy) by incorporating the haunting secret of the love between Karola and Miklós Bánffy. Uzdyne Adrienne, an unhappily married woman, loves Balint but their love faces numerous obstacles amid baroque Hungarian politics and mundane intrigues. One of the most striking parts of the novel is the description of Adrienne, modelled after the image of young Karola. The novel portrays this extraordinary woman in the following way:

Perhaps Adrienne's strange beauty played its part but Balint's awareness was casual not emotional, and he admired her as he would have admired a fine jewel or an exquisite bronze. Adrienne's figure was slender and still very girlish, yet her walk, light but in some way determined, reminded him always of a painting of Diana the Huntress he had once seen in the Louvre. She seemed to have the same elongated proportions, the same small head and supple flexible waist that the artist had given the goddess when she reached over her shoulder to take an arrow from its quiver. And when she walked she had the same long stride. Her coloring, too, recalled the Diana of his memory, the clear ivory skin with slight golden tints which never varied from her softly shining face to her neck, and the arms and shoulders that emerged from the silken décolleté of her ball-dress. Only her hair was different, and her eyes, for whereas Diana was blonde and blue-eyed, Adrienne's hair was dark and wavy and alive - and her eyes were onyx, flecked with golden amber. (Bánffy 1999: 17)

[Kétségtelen, hogy Adrienne szépsége is közrejátszott, de Bálint úgy érezte, hogy csupán tárgyilagosan tetszik neki, mint ahogy valami finom ékszer vagy egy kiváló bronz. Tetszik az a sudár, még nagyon leányos termete, az a könnyü és mégis eröre valló járása, 
melynek látásánál mindig a vadászó Diána képére kellett gondolnia, mely a Louvre Fontainebleau-termének egyik kincse. Ugyanazok a kissé elhosszabbitott arányok, az a viszonylag pici fej, az a rugalmas visszahajló derék, amint az istennö egyik kezével a válla fölött egy nyilat vesz ki a hátán függö tegezböl. Ugyanaz a sima, hosszú kilépés. És a szín is az: egyenlöen elefántcsontszínü bör, mely mintha halványan be volna aranyozva. Ilyen halkul világító az arca, a nyaka, a karja, ilyen a váll is a báli ruha kivágott nyílása fölott. Csak a haj más és a szeme, mert az a Diana szöke és kék szemü, míg Milóth Adrienne-nek barna hullámzó haja van, melyet mintha mindig valami vihar lobogtatna és sárga borostyánkö szemei.] (Bánffy Miklós A fali írás első szava: Megszámláltattál ['The Writing on the Wall. Vol 1. They Were Counted'] (1934), Kolozsvár: Polis-Kalota, 2002: 14)

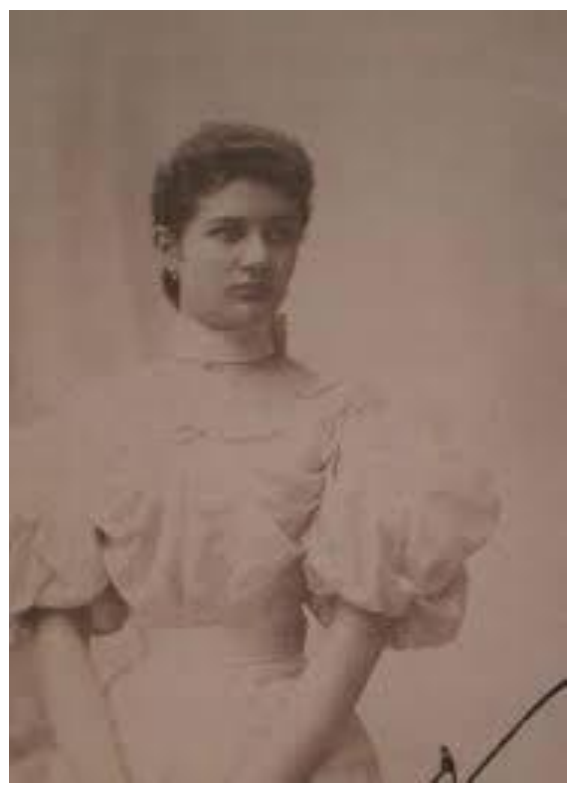

Young Karola Szilvássy

Adrienne is naturally more than a beautiful woman: she is an erudite person, versed in many areas within her own Central European culture. Like Szilvássy, she is strong, energetic, independent who stands out by rebelling in various ways against the rigid norms her society would impose on her. Not only was Adrienne beautiful, but she was always interesting to talk to as her ideas were her own as well as very individual for a young woman of her background and it therefore was not necessary to avoid subjects such as foreign affairs, history or literature as one did with many young girls who would otherwise take offence at a display of such seemingly superior knowledge. Adrienne also rebelled against the type of romantic literature girls of her age were expected to enjoy, for at the finishing school in Lausanne where she had been sent she was exposed to Flaubert, Balzac, Ibsen and Tolstoy, and since this time the trivial no longer appealed to her (Bánffy 1999: 17).

The Transylvanian Trilogy furthermore includes a love triangle made up of Adrienne (Karola Szilvássy), Balint (Miklós Bánffy) and Adrienne’s husband, Pal Uzdy (Elemér Bornemissza). The Bornemisszas, who married when Karola was twenty and decided to live 
separately after the death of their child seven years later, were the models for Bánffy's Uzdy couple. In the novel, wealthy Uzdy, a sadist hunter was trying to dominate his autonomous wife not only in private but also in public. Balint is aware of Uzdy's strategy, which he finds utterly insupportable, especially during a dinner scene when the host flaunts his ownership of Adrienne in front of the guests (Bánffy 1999: 429).

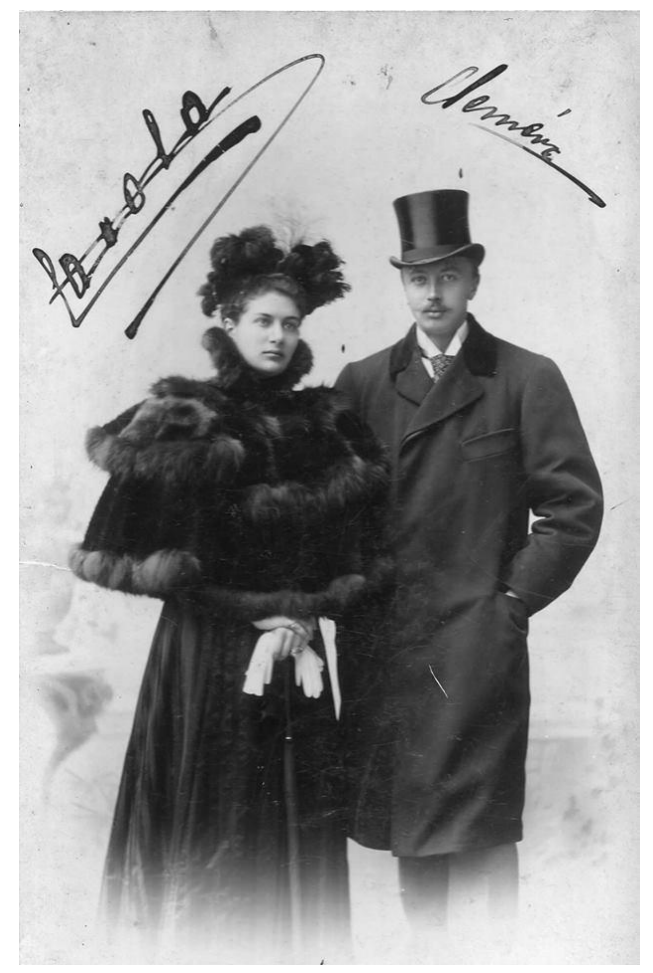

Baroness Elemérné Bornemissza Karola Szilvássy with her husband, Baron Elemér Bornemissza

The seemingly simple formula of the Balint-Adrienne-Uzdy aristocratic romance triangle reveals unexpected complexities involving two pivotal triangular structures. According to Enikö Bollobás (2018a; Bollobás 2018b: 48, 54), one is the typical or patriarchal structure, characterized by hierarchy, fixed positions, and rivalry for domination, while the second format is the atypical or intersubjective characterized by non-hierarchy, shifting positions, reciprocity and interchangeability. The triangular romance of The Transylvanian Trilogy displays exactly this intricate pattern: it is a combination of these two aforementioned categories by having a hierarchical, one-directional, fixed position seen from the vantage point of Uzdy's patriarchal character par exellence, combined with an intersubjective triangle design that reflects the equality of its subjects, Adrienne and Balint. However, as stated by Bollobás, only intersubjective triangles are truly triangular because the selves mutually engage with each other, experiencing other subjects from fluid and changeable positions. Due to Adrienne and Balint, this is the case in Bánffy's novel as well, even if this intersubjective structure contains, in an unheimlich manner, also patriarchal relations. This unheimlich ['uncanny'] aspect of strong patriarchal presence within the trilogy's intersubjective triangle brings forth the state of what Pál Hegyi (2017) calls the state of "being unsecretly," in a permanent motion amplified by 
Cristian, Réka M.. "The Life and Times of Karola Szilvássy, A Transylvanian Aristocrat and Modern Woman.” Hungarian Cultural Studies. e-Journal of the American Hungarian Educators Association, Volume 12 (2019) DOI: 10.5195/ahea.2019.359

progressive relations to the absent secret that maintains these triangles in narrative motionunlike in real life, with the Bornemisszas finally living separate and the relation between Karola and Miklós lasting for more than fifty years as a romantic friendship. Miklós Bánffy, however, "was a discreet man; in his memoirs he writes not a word about Carola Bornemissza" (Scholten 2016: 102).

Aladár Kuncz, another famous Transylvania writer, illustrates a portrait of Szilvássy that bears great resemblance to Bánffy's in Felleg a város felett ['Clouds Over the City'], although in Kuncz's work Szilvássy is not the protagonist. Kuncz (1940: 96-98) depicts Karola as a nonconformist whose Kolozsvár house was furnished, unlike other houses, with no family portraits on her wall, but instead displayed an original Cézanne, two Picassos, a painting by Károly Kernstock and another by József Rippl-Rónay, as well as many modernist sketches and intriguing drawings. A music score by Achille-Claude Debussy lay open on her piano and the books in her bedroom included volumes by Anatole France, Romain Roland, Bernard Shaw, Gilbert Keith Chesterton, Gerhart Haptmann, Christian Friedrich Hebbel, among a myriad of others. Similar to many of her contemporaries living in the multiethnic towns of the monarchy for whom the high culture of the Habsburg Empire provided a specific intellectual horizon, Szilvássy embraced what Perloff (2016: 3) calls the Austro-Modernist innovative spirit and committed herself to creating her own modes of expression both in her private and public world. Just as in Kuncz's depiction of Szilvássy, Bánffy's Adrienne is also an avant-garde, modern woman, who - similar to Karola - thinks marriage is an obsolete, meaningless institution that unnecessarily restricts individual freedom. Moreover, Adrienne believes it is every person's right to choose her or his way of life. Later on in the first volume of the trilogy, Bánffy's (1999: 273274) words actually paraphrase Karola's thoughts on love and freedom in his insightful description of Balint's love.

Other than Bánffy and Kuncz's literary portraits, Ovary's account of the rebellious Szilvássy in his Souvenirs: Around the World in Ninety Years, A Book of Memoirs presents an analogous picture. Szilvássy's godson writes that,

[s]ome people in town criticized her for not staying at home in the evening, like a proper woman. But she had very strong beliefs about the rights of women and of individuals. By the 1920s, she was coming to dine with us every single night, except when she was away in Venice or Budapest. My mother always reserved the place of honor for her, the seat to the right. She became so much a part of our evenings.... (Ovary 1999: 34)

Like her literary image, Szilvássy was a "striking person” in all regards (Ovary 1999: 32). As Ovary recalls, he was less impressed in his childhood by his godmother's informal attitude and broad knowledge of arts and culture than by one of her adventures which made her legendary: her flight with one of the pioneers of aviation, Louis Bleriot. Ovary relates the aerial voyage of Szilvássy in the following excerpt; according to the immunologist, was among the first flights with a woman passenger on the board of an airplane at the advent of aviation:

[w] hen Louis Bleriot, the French airplane inventor, visited Budapest she went there to witness the first airplane flight in Hungary. She then told her husband, the Baron Elemér Bornemissza, that she would like to fly with Bleriot. The Baron went and spoke to Bleriot. However, Bleriot could not imagine taking up a private person and, of all the 
most bizarre notions, a woman at that! He didn't want to make a direct refusal, so he quoted the out-of-this-world charge of 10,000 crowns in gold. The Baron said that he was not in the habit of carrying this amount of money, but if Bleriot would wait for half-anhour, he would send somebody to his bank. Bleriot could not believe it, but in half an hour, he got the sum he quoted. This was how my godmother became the first woman in the world to ever fly. At that time, this was seen as a great leap forward for women's rights! (Ovary 1999: 32-33)

As Szebeni states in her interview for the Hungarian Program Erdélyi Figyelö ['Transylvanian Observer'] of TVR (Televiziunea Româna) ['Romanian Television]' Kolozsvár, Louis J. Ch. Blériot's visit to Budapest in 1909 is a historical fact proved by documents. The first person to ever fly across the English Channel in a powered aircraft, the French aviator flew the airplane he designed over the Channel between northern France and southern Great Britain in July 1909; in the fall of the same year Blériot visited Budapest, where he exhibited his aircraft later named the Blériot XI Monoplane (a piloted, powered airplane type, the inventor's most successful model) in the Vigadó Galéria ['Vigadó Gallery']. During the early days of aviation, it was not only unusual but also quite dangerous to take passengers aboard and pilots seldom did so; the Wright brothers, for example, took Charles Furnas with them in 1908, while Blériot flew with Santos Dumont and another man as passenger in a 1909 flight. In spite of the fact that Karola Szilvássy's flight over Vérmezö ['Blood Fields,' a section of Budapest] during a second visit of Blériot in 1912 was not recorded officially nor reported afterwards in the media, a number of first-hand accounts of this episode (including that by Ovary) attest that Szilvássy was the first woman in Hungary (and not in the world, as Ovary over-enthusiastically claims) to fly. Szebeni further adds to the credibility of these accounts by claiming that Karola's personality was truly compatible with an adventure of this proportion (Szebeni 2014).

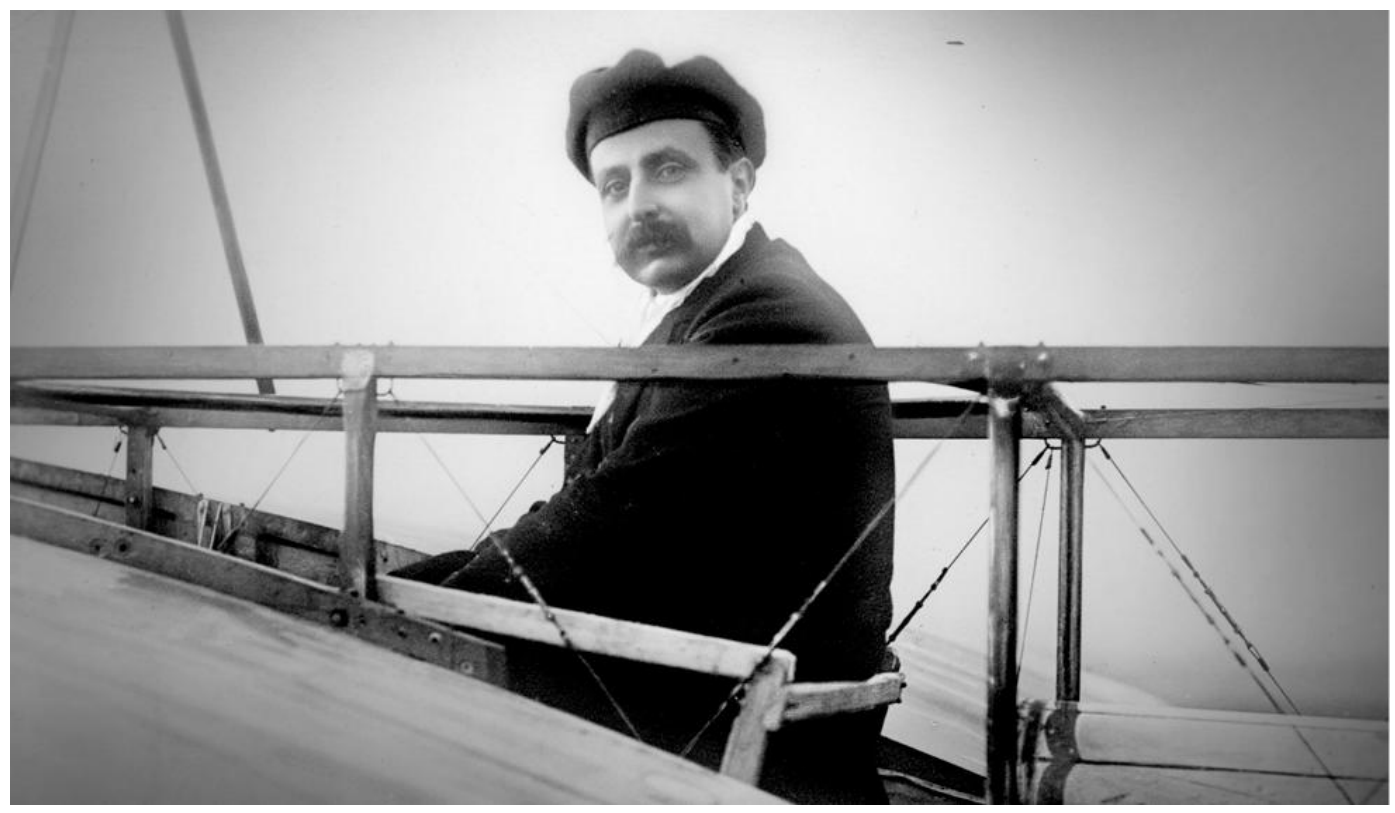

Louis J. Ch. Blériot (1872-1936) before the 1909 English Channel crossing 


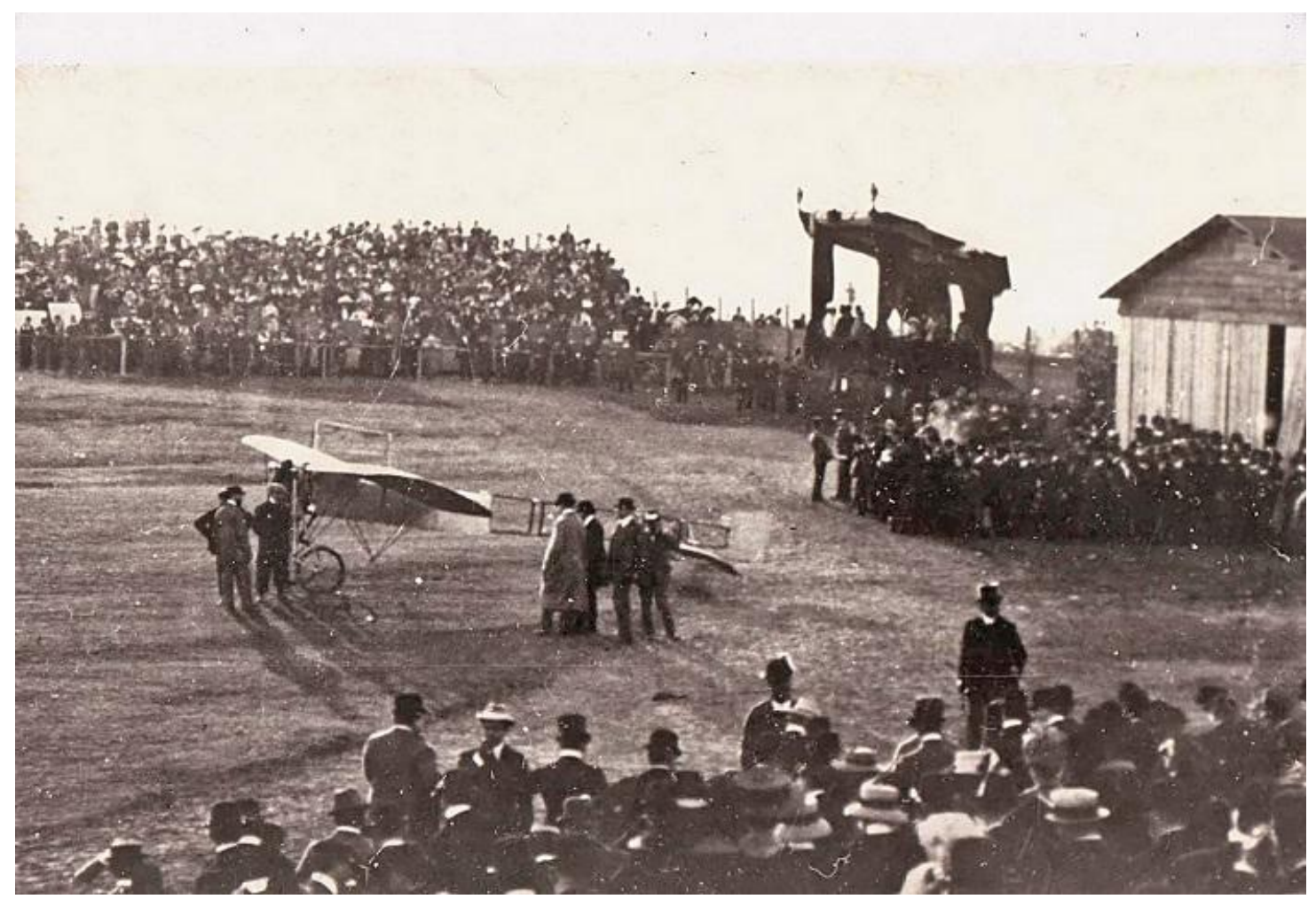

Blériot's first flight over Vérmezö ['Blood Fields'] on October 17, 1909

Szilvássy’s insubordinate personality also appears in János Kemény’s Kakukkfiókák. Önéletírás ['Cuckoo Chicks. An Autobiography'], in which this American-Hungarian count born in Pittsburgh, Pennsylvania describes her as an unwavering person and a fearless woman full of surprises. Indeed, Szilvássy was a temperamental woman who could both hate and love with equal intensity. She was admired for her joie de vivre and belief that life was always interesting and exciting even in its most difficult moments. Karola's militant outspokenness and her straightforward behavior brought her quite a number of enemies in high society - who considered her a poisonous presence and a purulent wound to be excised from the Hungarian aristocratic world - but in turn, this generated more friends and admirers among the poor. One case in particular created general outrage among the middle and upper classes: Szilvássy saved the pregnant partner of an executed murderer by giving her shelter after she had been ousted from her home due to her connection to a convict. Shocked at how the expectant mother was being treated, Karola declared that this woman and her soon-to-be-born child were not responsible for the crimes of the killer. Moreover, as all humans do, they also had the right to a roof over their head. Szilvássy subsequently permitted the young woman to stay in her house for as long as she wished. The woman moved into the Bornemissza home located on Kolozsvár's Monostori Street, where she gave birth to her child and then stayed on as Karola's helper until the end of her life (Kemény 1972: 285).

After losing her son, Karola only wore black and white clothes and lived apart from her husband, with whom she still remained in touch (Scholten 2016: 101; Kemény 1972: 285). 
Cristian, Réka M.. "The Life and Times of Karola Szilvássy, A Transylvanian Aristocrat and Modern Woman.” Hungarian Cultural Studies. e-Journal of the American Hungarian Educators Association, Volume 12 (2019) DOI: 10.5195/ahea.2019.359

Inconsolable with grief, she even travelled to Africa in 1908 in an attempt to forget the death of her beloved child. Fortified with a letter of recommendation from the Countess of Selborne, an ardent activist for women's equality and suffrage, Karola together with Baroness Elemérné Aczél, néé Mária Wass started her intrepid journey to pay homage to her cousin, the freedom fighter count Albert Wass, Jr. (Siemers 1999: 163-164). Despite serious warnings about the dangers of such a trip, the two courageous women decided to go forward with only few companions through the less charted, wild territories of South African Transwaal, where Albert Wass, Jr. had been buried. Since this region could not be reached by vehicle, Karola and Mária "travelled across South Africa by train, boat and donkey, to erect a gravestone for a cousin who had fought in the Boer War [1880-1881, 1899-1902] and died in battle" in 1902 (Scholten 2016: 99). With their aim accomplished, Karola and Mária returned to Hungary after a brief visit to the Victoria Falls on the Zambezi River.

Throughout her life, Szilvássy was in very good physical condition due to a healthy diet and lifestyle, another factor that contributed to the success of her strenuous journey to Africa. A genuine New Woman, she practiced various sports during the fin de siècle when sportswomen in Austria-Hungary and in the world were the target of criticism because they presented a cultural challenge and threat to conventional ideas about the ideal womanhood. At the beginning of the twentieth century, sports for women were some of the few areas of resistance to male domination and few women were involved more seriously in physical education. Szilvássy had her own, free-spirited way of practicing sports: not only did she swim regularly, but she also liked to swim in the nude (Scholten 2016: 101). With an athletic body even in her sixties "she was of such healthy constitution" that Ovary (whose first patient was Szilvássy) ended up "giving her nothing but regular checkups" because she was always in "perfect condition" (Ovary 1999: 73-74).

In her youth, Karola devoted a great amount of time to theater, dance, and music. Her vanguard, ingenious look also reflected her profound love of the visual arts. She was primarily attracted to theater (her role model being Sarah Bernhardt) and, as a child acted in several minor plays. She later performed in a French drama in 1902 and in Henrik Ibsen's A Doll's House, as well as participating in Kolozsvár's theater scene under the mentorship of theater director Jenő Janovics. Although very few documents connected to Szilvássy remain from this period, a few photos attest her love of acting, which could not be fully fulfilled due to a speech impediment.

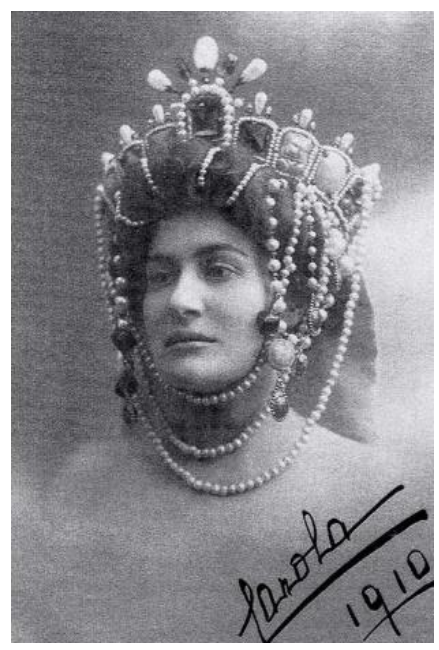


Cristian, Réka M.. "The Life and Times of Karola Szilvássy, A Transylvanian Aristocrat and Modern Woman.” Hungarian Cultural Studies. e-Journal of the American Hungarian Educators Association, Volume 12 (2019) DOI: 10.5195/ahea.2019.359

Karola Szilvássy in 1910

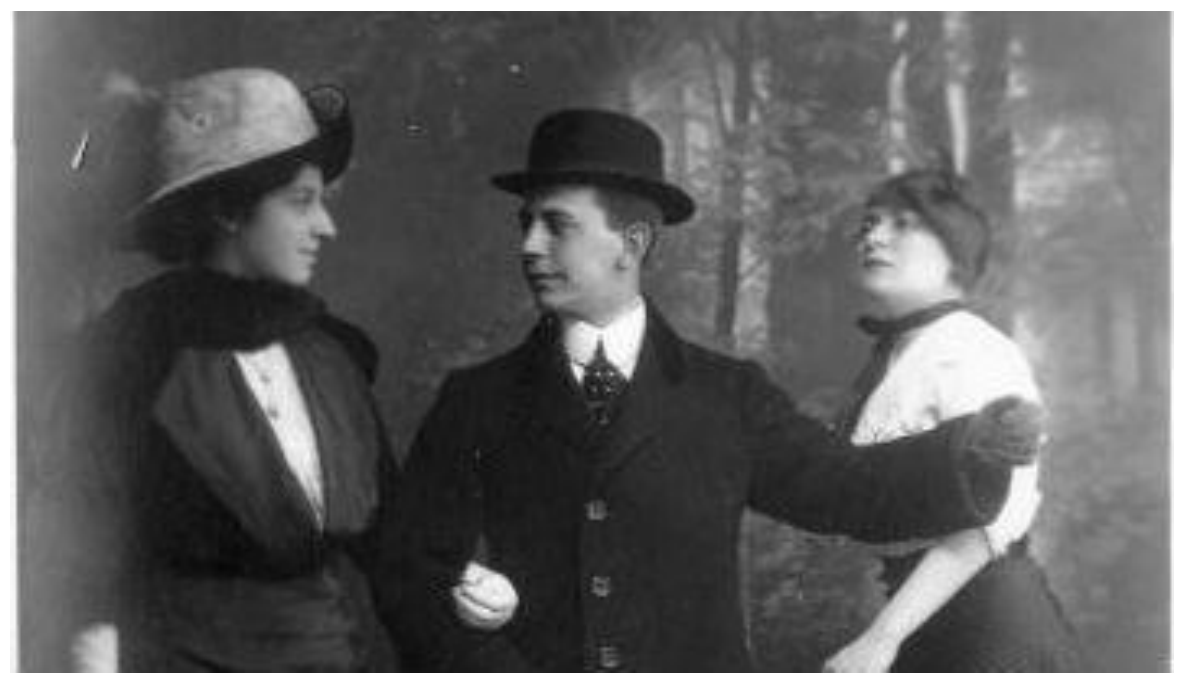

Egy végrendelet következményei ['Outcomes of a Last Will'] with Karola Szilvássy Bornemissza (on the right) in the role of Bányainé Gabrielle

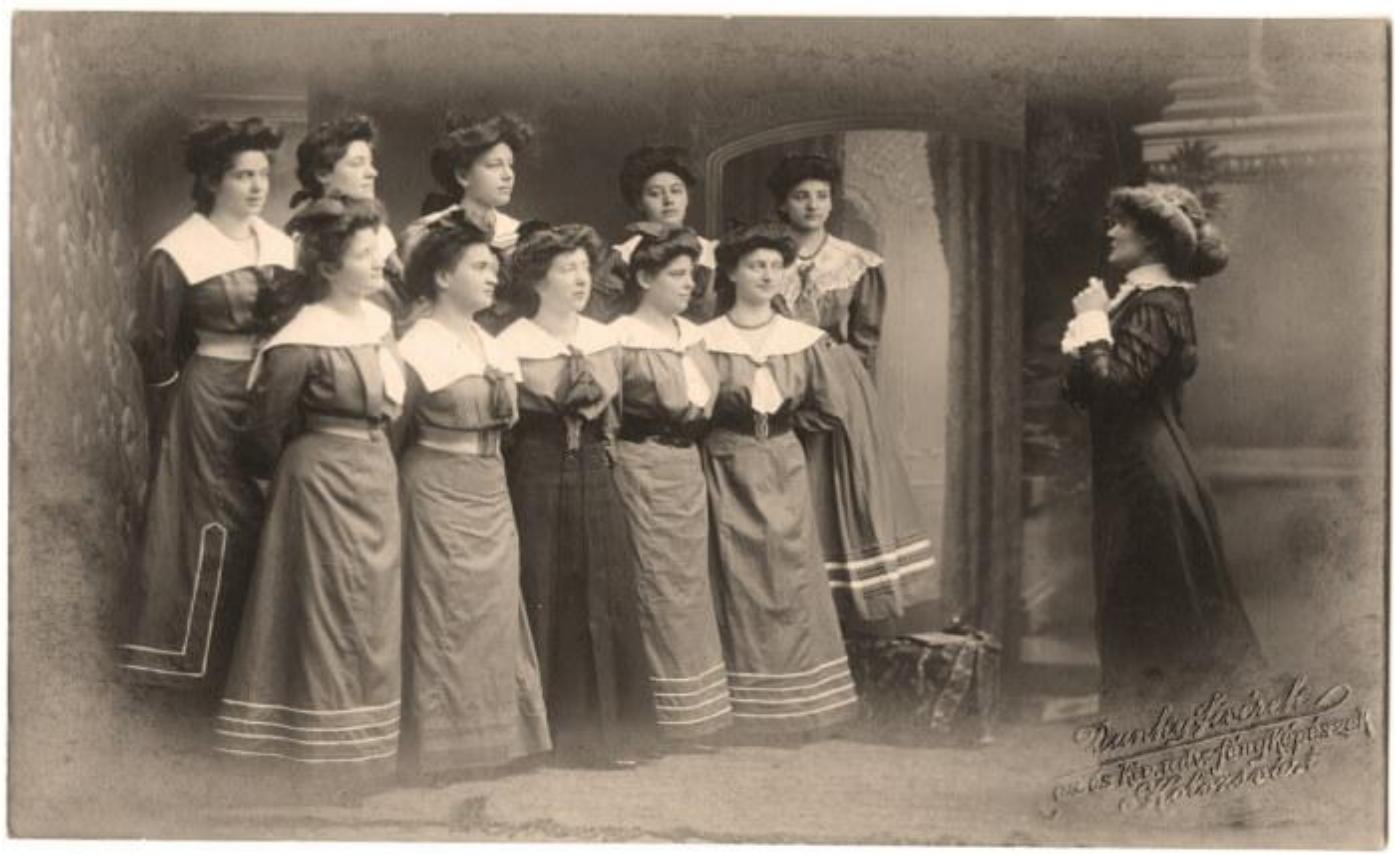

Szilvássy (on the right) directing a women's choir in Kolozsvár in 1910

Since she could not engage in a stage career, Szilvássy turned to silent film instead, a new, intriguing form of art in her time. During the first decade of the twentieth century, soon after the first studio of silent films was established in Inceville, California (1912), Szilvássy's support of artistic advances materialized in her participation in a silent film project in Transylvania as both the screenplay writer and film director. In the 1910s, only a handful of 
women active worldwide in the film industry; with her participation in the making of a silent movie, Szilvássy secured a place on the list of her contemporary women filmmakers, including Alice Guy Blaché (1873-1968), Lois Weber (1879-1939), Elvira Notari (1876-1946), Germaine Dulac (1882-1942), Anna Hofman-Uddgren (1868-1947), Mabel Normand (1892-1930) and many others. In this burgeoning, male-dominated industry, she directed (together with Elemér Hetényi) a film sketch, a very popular, hybrid film genre in Europe before the First World War, that was entitled Az apacsnö szerelme ['Love of the Apache Woman']. This film was to be presented, according to the local newspaper Újság ['Journal'], in the spring of 1913 at the bazaar of the Women's Association in the capital of Transylvania.

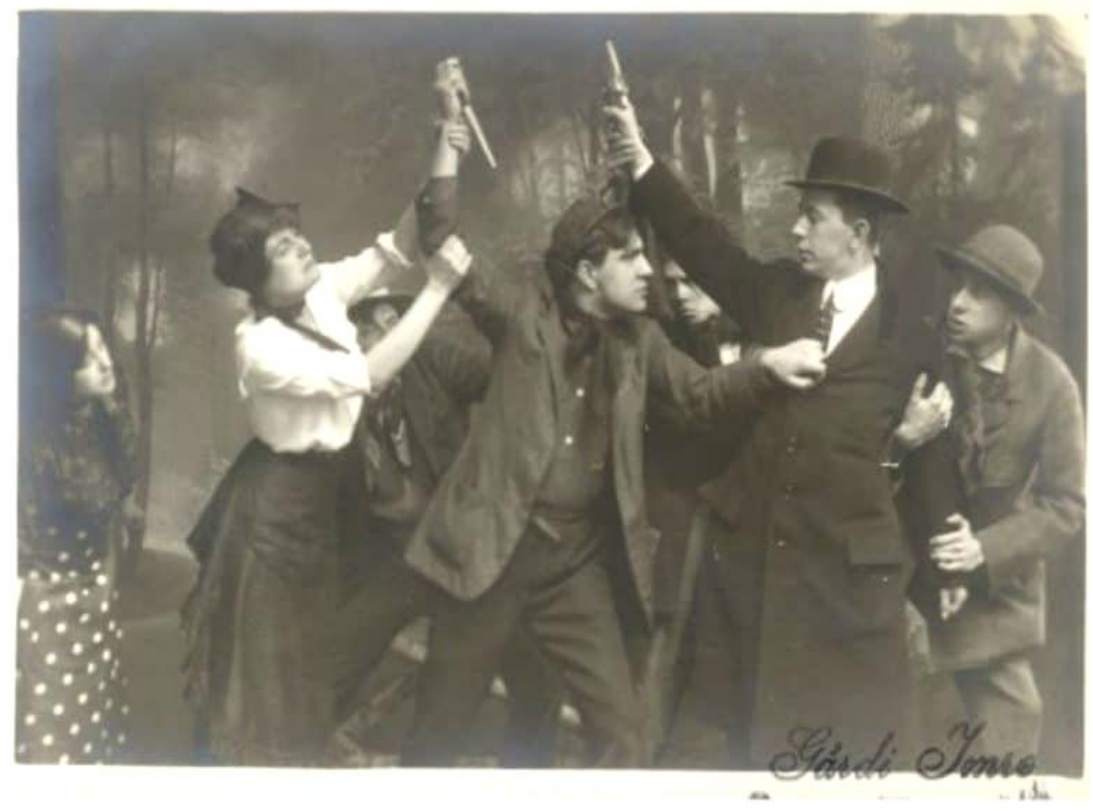

A scene from Az apacsnö szerelme ['Love of the Apache Woman,' 1913] directed by Elemér Hetényi and Elemérné Bornemissza Karola Szilvássy

Az apacsnö szerelme was the third film made in Kolozsvár. A cultural segment of what Perloff (2016: 7) calls the Austro-Modernism of the peripheries, the movie showed Transylvanian realities filmed in the city's brick factory on Donát Street, on the banks of the Szamos River, on the city's promenade and center, among Státus quarter's houses in construction, in the Bíró pharmacy and the New York restaurant, in the Thália coffeehouse and in and around the Bánffy-house and the church. The main role of the untamed, lawless Apache woman was played by Karola, while all other roles were played by a network of supporting fellow aristocrats (Szebeni 2018). The production of this movie was secured by the Budapestbased Uher film factory, with Ödön Uher and two cameramen present on the set (Moldován 2005). Despite the fact that the film's end result was technically impeccable, the March 8, 1913 of Ujsság ['Journal'] delivered a dreadful critique of the film (qtd. in Moldován 2005). Similarly to the disappearance of the lady in George Méliès's 1896 work, L'Escamotement d'une dame ['The Vanishing of a Lady' or 'The Conjuring of a Woman'], Szilvássy was afterwards hardly mentioned in film reviews or in any other documents. Indeed, in the early days of the cinema, especially Méliès's cinematic sketches coincided with the removal of the woman from the 
Cristian, Réka M.. "The Life and Times of Karola Szilvássy, A Transylvanian Aristocrat and Modern Woman.” Hungarian Cultural Studies. e-Journal of the American Hungarian Educators Association, Volume 12 (2019) DOI: 10.5195/ahea.2019.359

intradiegetic world, marking her destined absence the condition for the birth of the narrative film (Dragon 2003: 15). Despite the fact that Szilvássy was then credited as the director of this film sketch, the history of Hungarian cinema enlists no female directors at all between 1901 and 1929 (Szilágyi), making her absence the condition for a potential revision of Hungarian film history regarding women directors.

After completing her film project, Szilvássy turned her interest in volunteering on the warfront to help soldiers in the First World War, which broke out the following year. Szilvássy worked as a surgical nurse in casualty clearing stations for which she was professionally trained receiving her diploma in midwifery from the Kolozsvári Magyar Királyi Ferenc József Tudományegyetem Orvostudományi Kar ['Medical School of the Royal Hungarian Ferenc József University in Kolozsvár'] on January 30, 1910 (Sas 1997: 32). Ovary writes that after the outbreak of World War I, his godmother assisted surgeons as an instrumentalist nurse in an army hospital located on the Russian front where she stayed for two years and was later highly decorated for her service there (Ovary 1999: 33). Apart from her work on the front, when she returned home Karola also payed special attention to orphan children as she was conscious of their extremely vulnerable situation, especially of those living in locations close to battles. In September, 1916, the city of Nagyszeben (Sibiu/Hermannstadt) was caught between two fronts: the Romanian army occupied the town's northern part, while the old city was held by Hungarian soldiers. When the children of the famous Római Katolikus Theresianum Árva-és Lelencház ['Theresianum Roman Catholic Orphanage'], which opened its gates to children in 1771, were in imminent danger, Szilvássy — with the help of Albert Dörr (the city's mayor), Miklós Bánffy, and Istvánné Bethlen Margit—organized their evacuation with twenty carriages she borrowed from the Hungarian army. They consequently saved thirty babies from the city's nurseries and seventy small children from Nagyszeben's preschools, along other fifty orphans from the Theresianum by transporting them to Kolozsvár (Sas 1997: 32). In recognition of her extensive work and service on the front and beyond, Szilvássy was decorated with the First Class of the Elizabeth Order in 1917 (Csapody 2016: 58). The Kaiserlich Österreichischer Elizabeth-Orden ['The Imperial Austrian Order of Elizabeth'], founded in 1898 by Emperor Franz Josef in honor of Empress Elizabeth of Austria (1854-1898) and Árpádházi Szent Erzsébet ['Saint Elisabeth of Hungary'], was an order of chivalry for women awarded for general welfare in religious, charitable, or philanthropic merit.

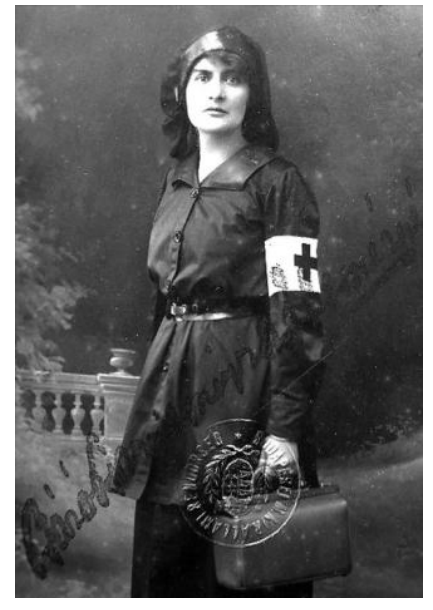

Karola Szilvássy during the First World War 
Cristian, Réka M.. "The Life and Times of Karola Szilvássy, A Transylvanian Aristocrat and Modern Woman.” Hungarian Cultural Studies. e-Journal of the American Hungarian Educators Association, Volume 12 (2019) DOI: 10.5195/ahea.2019.359

After the war Szilvássy returned to her house in Kolozsvár and immersed herself in the social life of the city by helping organize and run communities of writers and artists. The trauma brought about by the end of World War I led to a sense of deracination in many of the creative spirits of the time, including Szilvássy's. In the cultural landscape of Translyvania in the 1920's and 1930's, she became an artist without a genre, one who could not fully evolve because of various historical reasons that changed the lives of many millions in Central Europe. By reaching out to various models of social, spiritual, and cultural innovation, she provided social support by enhancing material assistance for local orphanages and houses for the old, alongside emotional support for young women and girls both within and beyond the Deaconess movement in Kolozsvár.

Szilvássy continued to be instrumental in every event and publication of the prolific Helikon group in Marovécs and Ováry-szalon in Kolozsvár. In 1928, she was elected memberpatroness of the Marosvásárhelyi Kemény Zsigmond Irodalmi Társaság ['Zsigmond Kemény Literary Society of Marosvásárhely (Târgu-Mureş/Neumarkt)'] (1876-1948; 1990-), a cultural and social society which facilitated the cultural dialogue among Hungarian writers from Hungary and Transylvania, as well as Romanian and Saxon writers from Romania. As can be found in the Romániai magyar irodalmi lexikon (Vol. I-IV) ['Romanian Hungarian Literary Lexicon'], the Zsigmond Kemény Literary Society supported literary, linguistic, ethnographical and musical events and was instrumental in the historical preservation of various cultural artifacts (historical markers, museum pieces) contributing to the modernization of the city's public history (Dávid 2006). As member-patroness of this society, Szilvássy funded a considerable stipend of 4,000 lei for the most talented highs school essay writers of the Marosvásárhely-based Református Kollégium ['Reformate College'], known today as the Bolyai Farkas Elméleti Líceum ['Bolyai Farkas Theoretical High School'] and closely followed the intellectual growth of the young artists and scholars there (Sas 1997: 33).

Little is known of Szilvássy's life during the 1930s and 1940s, by which time she was rarely seen at public events and balls (Sas 1997: 34). Her gradual withdrawal from public life mirrored her own state resembling the "peculiar statelessness" which Perloff (2016: 127) aptly referred to that resulted from the demise of the Austrian-Hungarian Empire in 1918. After 1945, half of Szilvássy's house was seized by the communist regime; as her life and health conditions worsened, Karola moved into the hospital of the Deaconess Institute of Kolozsvár (Sas 1997: 34) where she died in 1948. Szilvássy was buried in the Házsongárdi temetö ['Házsongárd/Hasengarten/Hajongrad Cemetery'] of Kolozsvár. Founded in the sixteenth century, Hazsongárd is one of the oldest cemeteries in Transylvania as well as among the largest in Central Europe; this final resting place for Hungarians, Romanians, Saxons and many other people of various religions and denominations is a worthy site for the last remains of a vibrant, restless, highly intelligent, European intellectual like Karola Szilvássy. 
Cristian, Réka M.. "The Life and Times of Karola Szilvássy, A Transylvanian Aristocrat and Modern Woman.” Hungarian Cultural Studies. e-Journal of the American Hungarian Educators Association, Volume 12 (2019) DOI: 10.5195/ahea.2019.359

\section{Works Cited}

Bánffy, Miklós. 1999. The Writing on the Wall. (Erdélyi Történet) The Transylvanian Trilogy. Book One: They Were Counted. Transl. Patrick Thursfield and Katalin Bánffy-Jelen. Foreword by Patrick Leigh Fermor. London: Arcadia Books/UNESCO.

Bollobás, Enikő. 2011. "Silenced Voices: Hungarian Plays from Transylvania." Hungarian Review 2/6: 118-125. Web: http://www.hungarianreview.com/article/silenced_voices - 2018 a. "Háromszögek az irodalomban—Vágyszerkezetek Máraitól Nádasig." ['Triangles in Literature - Structures of Desire from Márai to Nádas'] Magyar Tudomány [Hungarian Science] 2018/05. Web: https://mersz.hu/dokumentum/matud_203

-----------. 2018 b. "Versions of Triangular Desire in Hungarian Literature: Reading Sándor Márai and Péter Nádas." Hungarian Cultural Studies. e-Journal of the American Hungarian Educators Association, Volume 11 (2018) DOI: 10.5195/ahea.2018.321

Bornemissza Báró, Elemérné Szilvássy Karola. [1998, 2001] 2007. Kipróbált receptek ['Tried Recepies.'] With a foreword and afterword by Ildikó Marosi. Third Edition. Csíkszereda: Pallas-Akadémia.

"Bornemissza Elemérné Szilvássy Carola hagyatéka" ['The Estate of Elemérné Bornémissza Carola Szilvássy'] 2014.05.30. In “A kolozsvári református gyűjtőlevéltár ismertető leltára" ['Inventory of the Kolozsvár Reformate Archives']. F Part - Personal Estates. F 16 Segment, 76-77. Web: http://reformatus.ro/20140530leveltar-ismerteto-leltara.html?pdf=1

Csapody, Miklós. 2016. "Amitié amoureuse. Gróf Bánffy Miklós és báró Bornemissza Elemérné Szilávssy Karola.” ['Amitié amoureuse. Count Miklós Bánffy and Baroness Elemérné Bornemissza Szilvássy Karola'] Korunk XXVIII/12: 54-65.

Csinta, Samu, ed. 2016. Arisztokraták honfoglalása. Erdély újranemesítői II ['Aristocrats' Conquest. Transylvania's Re-ennoblers']. Budapest: Heti Válasz.

Dávid, Gyula. gen. ed. 2006. "Kemény Zsigmond Irodalmi Társaság.” ['Zsigmond Kemény Literary Society']. In Romániai magyar irodalmi lexikon Vol. I-IV. (A-R) ['Romanian Hungarian Literary Lexicon, Vol. I-IV. (A-R)']. Bukarest - Kolozsvár - Budapest: Kriterion Könyvkiadó ['Kriterion Publishing House'] - Erdélyi Múzeum Egyesület ['Transylvania Museum Society'] - Országos Széchényi Könyvtár Magyar Elektronikus Könyvtára ['Hungarian Electronic Library of the National Széchényi Library']. Web: http://mek.oszk.hu/03600/03628/html/k1.htm

--------. 2012. “The Inconvenient Grand Seigneur.” In Hungarian Review. III/1. 23 January 2012. Web: http://www.hungarianreview.com/article/the_inconvenient_grand_seigneur_ Dragon, Zoltán. 2003. "A nő eltünése, avagy a filmtörténet a femme fatale szerint." [ 'The Disappearance of the Woman or Film History According to the Femme Fatale.'] Filmtett 32/5: 15-17.

Fermor, Patrick Leigh. 1999. "Foreword.” In The Writing on the Wall. (Erdélyi Történet) The Transylvanian Trilogy. Book One: They Were Counted. Transl. Patrick Thursfield and Katalin Bánffy-Jelen. Foreword by Patrick Leigh Fermor. London: Arcadia Books/UNESCO: i-viii.

Gróf Bánffy, Katalin. 2014. Ének az életböl ['Song from Life']. Budapest: Helikon. Hegyi, Pál. 2019. Lovecraft Laughing. Szeged: Americana eBooks. 
Cristian, Réka M.. "The Life and Times of Karola Szilvássy, A Transylvanian Aristocrat and Modern Woman.” Hungarian Cultural Studies. e-Journal of the American Hungarian Educators Association, Volume 12 (2019) DOI: 10.5195/ahea.2019.359

Kemény, János. 1972. Kakukkfiókát. Önéletírás [ 'Cuckoo Chicks. An Autobiography']. Bukarest: Kriterion.

Kuncz, Aladár. 1940 [1931]. Felleg a város felett ['Clouds Over the City’], Budapest: Révai. Moldován, Árpád Zsolt. 2005. "Az erdélyi némafilmgyártás a korabeli magyar sajtó tükrében" ['Transylvania Silent Movies in the Light of the Period's Hungarian Press'] Filmtett. January 15. Web: https://www.filmtett.ro/cikk/2297/az-erdelyi-nemafilmgyartas-akorabeli-magyar-sajto-tukreben-uttoro-vallalkozas-vegyes-fogadtatas

Ováry, Zoltán. 1999. Souvenirs: Around the World in Ninety Years, A Book of Memoirs. New York: India Ink Press.

Perloff, Marjorie. 2016. Edge of Irony. Modernism in the Shadow of the Habsburg Empire. Chicago and London: The University of Chicago Press.

Sas, Péter. 1997. "Bornemissza Elemérné Szilvássy Karola." Müvelödés I./9: 31-35.

Scholten, Jaap. 2016. Comrade Baron. A Journey to the Vanishing World of the Transylvania Aristocracy. Transl. Liz Waters. Reno, Nevada: Helena History Press.

Siemers, Ilona. 1999. Wass-Kor. ['Wass/Iron-Age'] Marosvásárhely: Mentor.

Szántai, János. 2015 "Szilvássy Karola 50 árnyalata” ['Fifty Shades of Karola Szilvássy'].

August 19, 2015. Web: https://foter.ro/cikk/20150819_szilvassy_carola_50_arnyalata

Szebeni, Zsuzsa. 2014. "Bornemissza Elemérné Szilvássy Karola—Emlékkiállítás." ['Bornemissza Elemérné Szilvássy Karola Exhibition'] TVR Cluj. Román Televízió. Kolozsvári Magyar Adás. ['TVR Cluj. Hungarian Language Program, Romanian Television, Kolozsvár'] Erdélyi Figyelö ['Hungarian Observer'] Web: https://www.youtube.com/watch?v=jTsc6UtmTvc

Szebeni, Zsuzsa. 2018. "Az első kolozsvári filmszkeccs nyomában. Szilávssy Carola és $A z$ apacsnö szerelme." ['On the tracks of the First Kolozsvár Film Sketch. Carola Szilvássy and The Love of the Apache Woman'] Filmtett. December 14. Web:

https://www.filmtett.ro/cikk/az-elso-kolozsvari-moziszkeccs-nyomaban-szilvassy-carolaes-az-apacsno-szerelme/

Szilágyi Erzsébet. n.d. "Filmrendezőnők a magyar és az egyetemes filmtörténetben" ['Women Directors in Hungarian and World Film History'] Szabadpart Nr. 7.Web: http://www.szabad-part.hu/szam7/komm/szilagyi.htm

Thursfield, Patrick. 1999. "Miklós Bánffy and the Transylvania Trilogy." In The Writing on the Wall. (Erdélyi Történet) The Transylvanian Trilogy. Book One: They Were Counted. Transl. Patrick Thursfield and Katalin Bánffy-Jelen. Foreword by Patrick Leigh Fermor. London: Arcadia Books/UNESCO: ix-xix.

Vasvári, Louise O. 2013. "Judit Szapor, Andrea Petō, Maura Hametz, Maria Calloni, eds. Tradition Unchained: Jewish Intellectual Women in Central Europe 1860-2000. Twelve Biographical Essays. Lewiston: The Edwin Mellen Press, 2012. ISBN 978-0-7734-29338, 460 pages." Hungarian Studies Review, Vol. 40/2, Fall 2013: 210-217. 